\title{
Com um lápis e um papel ... cria-se um novo texto: as representações de práticas democráticas nos Colégios de Aplicação
}

\author{
Míriam Abduche Kaiuca
}

\section{Resumo}

Este artigo apresenta uma pesquisa sobre as representações que os professores do Ensino Fundamental dos Colégios de Aplicação da UFRJ e da UERJ constroem sobre a escola pública democrática. O objetivo geral foi o de apreender a dinâmica de construção das representações de uma escola democráti$\mathrm{ca}$, procurando verificar suas motivações históricas e ideológicas e as mudanças que sofreram ao longo do tempo; os valores, as normas, as atitudes, os símbolos e as resistências docentes ao processo de democratização das práticas pedagógicas contemporâneas. As representações docentes sobre a escola democrática articulamse ao projeto de educação que está em curso nos CAps ou foi implantado em outra conjuntura histórica, projeto esse que assume o referencial de escola pública, democrática e de qualidade. No cruzamento dos discursos surgiram as categorias norteadoras para análise dos dados: alteridade, poder e resistência. Concluiu-se que a educação democratizante não pode basear-se em qualquer noção a-histórica e transcendente de verdade ou autoridade. Foram encontradas representações que conservam a
Míriam Abduche Kaiuca Mestre em Educação, Universidade Estácio de Sá. Profa. do Núcleo Comum de $1^{\mathrm{a}}$ a $4^{\mathrm{a}}$ Série

do Ensino Fundamental, CAp/UFRJ função original seletiva e elitista dos CAps; representações que defendem uma formação diferenciada de acordo com a proveniência de classe social do estudante que ingressa no CAp e, finalmente, representações que reforçam a possibilidade de implantação de um projeto educacional que avance na direção do reconhecimento do aluno das classes populares e de sua integração na vida escolar.

Palavras-chave: Colégios de Aplicação. Escola pública democrática. Representações docentes de práticas democráticas. 


\section{O texto de uma professora no recorte de uma realidade}

$\mathrm{Na}$ perspectiva de uma educação democrática, as relações ficam mais evidentes quando se percebe, segundo Silva, que "não há como negar [...], que os processos de inclusão ou exclusão escolar estão conectados ao processo de inclusão e exclusão sociais." (SILVA, 1996, p. 47). Esse pressuposto nos impulsionou a refletir sobre o processo de constituição dos Colégios de Aplicação da UFRJ e da UERJ como possíveis espaços democráticos, sobre as ideologias que permeiam suas ações concretas e sustentam as representações que os sujeitos do processo educativo neles desenvolvidos têm da realidade, observando que é nas relações sociais que tais representações sociais ganham sentido, estabelecendo certos valores, conservando-os ou não.

Os Colégios de Aplicação criados no país são instituições públicas de educação básica ligadas às universidades e que estabeleceram como objetivos: a educação de adolescentes, o treinamento de licenciandos e a pesquisa pedagógica. Umas das suas principais características é ter assumido o compromisso da universidade com o ensino, a pesquisa e a extensão. Podem atuar diretamente na formação contínua de professores das redes municipal e estadual, multiplicando seus efeitos em projetos de interação contínua com os demais docentes das redes públicas, capazes de possibilitar um espaço de experimentação pedagógica para os futuros professores, integrando a educação básica e o ensino superior, na busca de alternativas metodológicas que dêem conta das diferenças e possibilitem rediscutir os conteúdos programáticos das disciplinas que integram a matriz curricular. A prática educativa dos Colégios de Aplica- ção, como em outras escolas, apresenta-se contraditória e está permeada pelas questões relativas às problemáticas sociais, em particular as relações de poder. É no jogo dessas relações que se afirma ou nega uma determinada concepção de escola democrática. $\bigcirc$ papel social e educativo dos Colégios de Aplicação qualifica-os como espaços formadores a partir da identidade de um ensino público, como assegura Jovchelovitch (2000, p. 31), "o espaço público ainda evoca um compromisso com um espaço social que pode ser recuperado no reconhecimento da multiplicidade de lógicas sociais que caracterizam a existência humana".

Ao pensar no espaço público estamos associando lógicas sociais e relações de poder com questões de cidadania, democracia e direitos. Dessa forma, o direito geral a uma educação de qualidade, enquanto parte da cidadania a ser conquistada, parece depender das mudanças do possível e do desejável nos espaços escolares, de acordo com Del Pettre (1993). Como pensar em mudanças escolares em espaços públicos nos Colégios de Aplicação contemporaneamente? Jovchelovitch salienta (2000, p. 60), que "a esfera pública não é só um conceito-guia no projeto de estabelecer a democracia, mas também um fenômeno histórico sujeito à avaliação e crítica". A esfera pública remete a uma idéia paradigmática para pensar democracia, escola democrática e a possibilidade de um espaço para o exercício do diálogo na vida comum e concomitantemente traz à tona problemas associados com as desigualdades sociais e as diferenças de distribuição dos bens culturais e educacionais. $O$ instrumento de trabalho da escola - o conhecimento sistematizado e escolarizado - é portador de compromissos, interesses e ideologias que lhe são subjacentes e que atravessam as relações entre construção simbólica e resistência. 
Elegemos como objeto de estudo na pesquisa' que realizamos as representações que os professores do Ensino Fundamental dos Colégios de Aplicação constróem sobre a escola pública democrática e como campo de investigação dois Colégios de Aplicação, o da Universidade Federal do Rio de Janeiro - CAp da UFRJ, e o da Universidade Estadual do Rio de Janeiro - CAp da UERJ. Ambas as escolas são públicas e prestigiadas, tanto no espaço da cidade, quanto no estado do Rio de Janeiro e ficaram conhecidas como "escolas diferentes" dentro do sistema escolar, como "escolas de qualidade". Em ambos os colégios, aboliu-se o recrutamento que era apoiado em provas intelectuais e testes psicológicos. $\bigcirc$ processo seletivo dos alunos das classes de alfabetização por sorteio público, no momento, constitui o dispositivo de ingresso institucional para as séries iniciais. Esta decisão foi assumida como mecanismo de rompimento com o caráter elitista dos Colégios de Aplicação e foi objeto de aplausos de alguns e críticas de outros. Assim, se no âmbito dos Colégios de Aplicação o sorteio não garante $O$ acesso a todos que desejam neles ingressar, garante, pelo menos, que alguns dos que possivelmente não entrariam pelo processo seletivo anterior agora se tornem estudantes da instituição. A história do sucesso dos CAps esqueceu os alunos que não podem estar compartiIhando de suas práticas, que foram afastados, os atores sociais calados, silenciosos, aqueles cujas vozes não têm sido registradas na história escrita dos vencedores. Nesse caso, já não se trata apenas de discutir o acesso, mas o acesso diferencial ao conhecimento, iá que existe no ponto de partida uma situação heterogênea, que a seleção anterior procurava contornar, para não dizer eliminar. Diante da mudança, é fundamental que se repense a garantia às diferenças culturais, de classe, de etnia, de gênero presentes na escola, sem cair na homogeneização, que massacra a diversidade, nem em políticas que celebram as diferenças sem a visão do processo constitutivo que as geram, mantém e hierarquizam a partir de critérios de universalização das concepções dos grupos dominantes. (OLIVEIRA, 1999, p. 60).

A heterogeneidade decorrente do processo de sorteio público amplia as possibilidades de serem pesquisadas alternativas pedagógicas para enfrentar os desafios de um processo de ensino-aprendizagem efetivamente plural. Isto significa que os CAps ao redefinirem seu universo de alunos, precisam redimensionar suas expectativas, seus conteúdos, suas estratégias, suas formas de avaliação, sem abrir mão da qualidade de seu trabalho. A busca dessa qualidade passa pela atitude de confiança no processo como um todo, com a avaliação contínua do caminho percorrido, o que pressupõe do professor-pesquisador, perfil exigido dos professores dos Colégios de Aplicação, um acompanhamento cuidadoso de todo o processo de ensino-aprendizagem.

A escola é uma importante instituição cabendo-lhe a responsabilidade de concretizar o projeto educacional da sociedade em seu conjunto, bem como da pessoa em relação aos objetivos por ela determinados, enquanto instituição, é uma disseminadora da ideologia dominante. Neste sentido, autores como Silva (1999), Althusser (1974), Bourdieu e Passeron (1983), entre outros, são incansáveis em denunciar que a escola, levando a cabo esses ideais, seja

\footnotetext{
${ }^{1}$ Dissertação do Curso de Mestrado em Educação da Universidade Estácio de Sá sob a orientaçâo da Prof. Dra. Clarice Nunes.
} 
no âmbito social, seja no âmbito pessoal, torna-se uma reprodutora de desigualdades sociais e preparadora de indivíduos submissos à ordem socialmente estabelecida. Esse papel de inculcação ideológica se evidencia na prática escolar, através da imposição de idéias mediatizadas por "práticas rituais escolares" que, na visão de Establet (1974, p. 41), vão além da materialidade dos atos, da simples expressão das idéias, porque "são na verdade as próprias idéias dos indivíduos, indissociáveis de sua ação" e se reforçam no dia-a-dia da seleção dos alunos e do funcionamento da escola. Por outro lado, há um outro tipo de percepção sobre o que poderia se esperar da escola, como destaca Hanna Arendt (2000, p. 65):

[...] para quem a escola teria o papel principal, o de ser mediadora entre a realidade social, de onde se origina o indivíduo e o seu destino de forma a produzir, distribuir bens coletivos determinados por essa própria realidade.

Desta forma, enquanto mediadora, a escola poderia estar engajada num processo de transformação que, para Gadotti (2001, p. 17), "se dá quando a experiência escolar faz alguma diferença no sentido de levar o indivíduo, mediante a superação das suas limitações, a mudar também, o seu destino social". A escola seria parte integrante da sociedade e, como esclarece Gramsci (1979, p. 14), "o agir dentro da escola é também agir dentro da sociedade da qual ela não pode ser separada". Para uma educação tornar-se suficientemente universalista exige-se um reexame crítico de certas abordagens de como a escola considera seu caráter de "oferta cultural" para atender sua demanda. Assim,
[...] toda a educação, seja ela autoritária ou liberal, sociocêntrica ou individualista, aristocrática ou plebéia, formalista ou realista, está comprometida com o mito da Caserna, com a idéia de uma ascensão em direção à luz, de uma ascese liberadora, de uma negação do ser imediato e do contexto imediato, e finalmente de uma supremacia do invisível. Sem o valor, sem o sentimento de uma consistência de valores (a qual implica também na universalidade), não há educação que tenha sustentação.

(FORQUIN, 2000, p. 131).

É por isso que nos fundamentamos no paradigma crítico reflexivo, onde os princípios epistemológicos subjetivistas conjugados aos valores do pesquisador podem permitir a utilização de uma metodologia dialógica e transformadora (DELUIZ, 2001) para analisar que representações que os educadores dos Colégios de Aplicação fazem de uma escola pública democrática. Empregamos o conceito de "representações sociais" tal como é desenvolvido em estudos de Jodelet (1993) e Moscovici (1990): como uma forma de saber prático que permite ao homem a apreensão, a apropriação e a atribuição de significados a objetos do real. As representações sociais são dinâmicas, produtos de determinações passadas e presentes que constroem conhecimentos sociais cuja finalidade é situar o indivíduo no mundo e, conseqüentemente, definir sua identidade social. Permitem conhecer a forma de pensamento característica de determinado grupo social e, integrar atitudes, valores, modelos, símbolos, imagens, estereótipos, normas e outras condutas que nortearam a análise de como eventos sociais ocorrem e 
como a escola democrática enquanto objeto social é construída. Não adianta teorizar como se forma uma escola democrática mas como os homens formam e atuam nesta composição de fazeres dessa cultura pedagógica no interior dos Colégios de Aplicação. Segundo Forquin (2000, p. 68), "a cada dez anos, os homens são confrontados com um universo físico, intelectual e moral que representa transformações de uma amplitude que as antigas representações não são mais suficientes". Os homens tornam-se, continua ele, "estrangeiros na esfera na qual são chamados a viver". Reconhecemos que, nessa perspectiva, há como que uma reversão de perspectiva entre a temporalidade cultural do homem e do mundo. É nessa dialética que irá se instalar o paradoxo dos Colégios de Aplicação com seus homens que falam e que produzem uma escola na qual as diferenças não implicam apenas em exploração e dominação, mas também na complementariedade entre os indivíduos e os grupos, dentro de um campo de cultura próprio dessas escolas. Nesse sentido, Orlandi (1999, p. 78) aponta que "[...] compreender representações sociais implica então conhecer não só o discurso mais amplo, mas a situação que define o indivíduo que as produz". $\bigcirc$ discurso apresenta uma tensão entre o mesmo e o diferente, entre o já dito e o que há a dizer, já que a "incompletude é a condição da linguagem" (ORLANDI, 1999, p. 39).

\section{Democracia, espaço público e sentido da Educação}

A democracia é uma cultura e não somente garantias institucionais, uma vez que é um sistema institucional que permite a uma sociedade ser simultaneamente una e di- versa. Sartori (2000a, p. 92) destaca que:

A democracia é entendida hoje como um ideal-limite, não uma realidade de fato. Na medida em que a sociedade procura alcançar este ideal, ela vai se constituir enquanto esfera social, política e educacional. Ela vai crescer, se desenvolver e se renovar.

A democracia, para Bobbio (1997), caracteriza-se tanto pelo consenso como pelo dissenso. $\bigcirc$ consenso, construído sobre os procedimentos necessários à viabilização do regime, coexistiria com o dissenso, conservando-se dentro de determinadas proporções, que contribuiria para a progressiva mudança da sociedade através da livre discussão de idéias e do desenvolvimento de "revoluções silenciosas". Do ponto de vista de Touraine (1996), a democracia para que tenha substância e seja valorizada com vigor e paixão, precisa ser vista como o regime que reconhece os indivíduos e as coletividades como sujeitos, protegendo-os e estimulando sua vontade de dar sentido a sua própria experiência. Para melhor compreensão sobre o tema, Sartori (2000b) demonstra que a premissa de que todos os homens são basicamente iguais garante a todos, pelo menos em tese, igual direito a participar da direção da sociedade. A democracia é o reconhecimento dessas condições em sua abertura e transparência, pois:

é necessária devido 'a pluralidade de interesses que se forma e 'a existência de conflitos insuperáveis de valores. A democracia é o meio político de salvaguardar a diversidade social e cultural dos membros da sociedade nacional ou local. (TOURAINE, 1998, p. 98) 
A democracia é a única possibilidade de limitar a crescente dissociação entre a racionalidade instrumental e identidades culturais. Por isso, precisa também de um espaço público que é social. $\bigcirc$ debate sobre a esfera pública não está obviamente circunscrito somente à sociedade capitalista ou neoliberal. Segundo Jovchelovitch (2000, p. 30), "o debate sobre a esfera pública encontra-se no centro das discussões relacionadas aos limites da democracia e da cidadania em sociedades contemporâneas". Se a democracia é o meio institucional para a formação do sujeito, o espírito democrático precisa estar presente também nas organizações. Além disso, a multiplicação dos espaços e processos de decisão possibilita aproximar as exigências impessoais que pesam sobre a ação e os projetos e preferências individuais. Essa aproximação -uma desmassificação- é feita pela educação. Rejeitando uma concepção puramente racionalista do homem e da sociedade, a educação deve formar a capacidade da ação racional de maneira que, lutando contra a aliança da razão com o poder, prepara uma aliança com a liberdade. Com a mesma importância, a educação deve voltar-se à aprendizagem da liberdade. $\bigcirc$ processo educativo, indo do espírito crítico e da inovação à consciência da própria particularidade - feita de memória histórica - deve culminar no conhecimento-reconhecimento dos outros, indivíduos e coletividades, enquanto sujeitos para construir sua própria identidade. A liberdade do sujeito pessoal não leva à renúncia à identidade e, por isso, a sociedade desempenha um papel essencial na formação do espírito democrático ( $\mathrm{BOBBIO}, 1997)$.

Se, atualmente, não se pode conceber qualquer sociedade contemporânea sem o funcionamento regular de um sistema escolar, menos ainda se pode imaginar um país democrático que não ofereça educação escolar aos seus habitantes. Desde que esta se tornou um direito, a existência de pessoas não assistidas pelos serviços escolares atenta contra o princípio da igualdade de direitos, ou seja, contra o respeito ao que lhes é fundamental. Entretanto, ao contrário do que essas constatações geralmente levam a crer, ainda que a oferta dos serviços escolares seja indispensável à democracia, isso não distingue por si só o caráter democrático de uma sociedade no que diz respeito à educação. A educação escolar pode se aproximar, afastar-se ou manter-se eqüidistante da democracia. Além de ser adequada à idéia democrática ou contrariá-la, a educação escolar pode também ser indiferente a ela.

Admitindo-se uma definição de democracia pela qual esta se constitui da interdependência do respeito pelos direitos fundamentais, da cidadania e da representatividade, Benevides (1998, p. 95) pontua que o "principal paradoxo da democracia persiste: ele não existe sem uma educação apropriada do povo para fazê-la funcionar, ou seja, sem a formação de cidadãos democráticos". Desta forma, faz-se necessário examinar também a contribuição da educação escolar como formação de personalidades democráticas, no sentido de maximizar a transformação de indivíduos e grupos em sujeitos. Anísio Teixeira, um dos maiores educadores brasileiros, é um dos mais destacados formuladores nessa perspectiva. Considerando a educação um processo de cultivo e amadurecimento individual, crescimento orgânico, humano, governado por normas científicas e técnicas, ele procura fazer da escola um instrumento para promover a democracia, enfatizando um tipo de educação que ele chama co- 
mum, que deve ser para todos. Ele estabelece que essa educação seja dominantemente pública como condição fundamental para assegurá-la universalmente (TEIXEIRA, 1956). Somente essa escola pública poderia ser "verdadeiramente democrática" acreditando que, nela, as diferenças de classe desaparecerão e todos os brasileiros se encontrarão para uma formação comum, igualitária e unificadora, destruindo preconceitos e prevenções.

\section{Colégios de Aplicação².}

A idéia de criar um laboratório ou colégios de demonstração ${ }^{3}$ em que fossem experimentadas novas metodologias e que, ao mesmo tempo, funcionassem como centro de referência na formação de novos professores finalmente ganhou forma e corpo com a fundação do Colégio de Aplicação da Universidade do Brasil, atual Universidade Federal do Rio de Janeiro (UFRJ), em 18 de maio de 1948. Há, desta forma, significativos indícios de que o ideário da escola nova estava presente na gênese dos CAps. Onze anos depois, em 1957, a então Universidade do Distrito Federal (UDF) criou o seu Ginásio de Aplicação da Faculdade de Filosofia, Ciências e Letras. Só mais tarde, em homenagem ao seu primeiro diretor e fundador, após a implantação do ensino médio (cursos Científico e Clássico), a escola passou a se denominar Colégio de Aplica- ção Fernando Rodrigues da Silveira, conhecido com CAp da UERJ, atualmente, como Instituto de Aplicação da UERJ.

\section{Os Colégios de Aplicação foram conce-} bidos a partir de duas premissas centrais: a de se constituírem em campo de estágio obrigatório para os licenciandos das Faculdades de Filosofia e o de oportunizarem a experimentação de novas práticas pedagógicas e, mantido em sua matriz o ideário das classes experimentais. Implantadas no Brasil seguiram sob o ideário do Manifesto dos Pioneiros da Escola Nova de 32 esclarecido com as seguintes palavras de Gildásio Amado, Diretor do Ensino Secundário,

dentro do sistema de uniformidade formal imposto por lei à escola secundária brasileira anos a fio, não se pode contestar que a implantação das classes secundárias experimentais em 1959 representa acontecimento rico de virtualidades, no sentido de abrir brechas no monólito educacional formado, restituindo à escola autonomia, capacidade de auto-afirmação e diversificação no processo educativo.

$$
\text { (AMADO, 1963, p. 93) }
$$

As classes experimentais implantadas no Brasil tinham não só um sentido de inovação pedagógica e curricular mas também um ca-

\footnotetext{
2 Para resgatar esse percurso, vali-me, especialmente, de fontes informativas. No que se refere ao CAp/ UFRJ, a obra Intelectuais e Guerreiros: o Colégio de Aplicação da UFRJ de 1948 a 1968, de Alzira Alves de Abreu, publicado pela Editora da UFRJ; o artigo "Contando a história do Colégio de Aplicação da Universidade Federal do Rio de Janeiro através de documentos", de Carla Nascimento Domingues, Fernanda Vasconcellos de Mattos e Helena lbiapina Lima; e o ensaio "Colégio de Aplicação", de Ernesto Campos, publicado na Revista Brasileira de Estudos Pedagógicos, vol. 28, n. 67, 1957.

Quanto ao CAp/ UERJ, foram consultados: o Boletim do CAp/UERJ, ano I, n. 1, maio 1997; o trabalho de dissertação de José Gonçalves Gondra, Trajetórias: origens e destino social dos alunos do CAp/UERJ, do ano de 1996; de Deise Mancebo a tese de doutorado intitulada: Da Gênese utilitária aos compromissos: uma história da Universidade do Estado de Rio de Janeiro (1950 - 1978), PUC/SP, 1995 e Regimentos do Colégio de Aplicação Fernando Rodrigues da Silveira.

${ }^{3}$ Inicialmente estes colégios são chamados de demonstração. No estudo de documentos da época recolhidos no PROEDES/UFRJ o nome de demonstração é corrente. A inauguração em 1948 do CAp/UFRJ se dá sob esta nomenclatura vindo, pouco mais tarde a chamar-se então de colégio de aplicação. No entanto, os documentos não evidenciam com precisão quando se deu esta mudança.
} 
ráter renovador na sua dimensão político-social. Desta forma, este caráter fica evidenciado em Nunes, quando apresenta o balanço das classes experimentais realizado por Cunha e Abreu (1963 apud NUNES, 1979, p. 68), que as escolas experimentais apresentavam uma quebra da rigidez curricular

no sentido de atender às necessidades, para alguns, de restauração da qualidade do ensino secundário, que não mais se enquadrava nos princípios de escola para elite, devido a sua expansão indiscriminada.

Defende-se a idéia de que as inovações pedagógicas propostas nesta experiência educacional realizada refletem o ideário da Escola Nova, sob alguma influência das comprehensive schools americanas e também de inspiração das "Classes Nouvelles" francesas. ${ }^{4}$ Segundo Nagle (1974) o movimento da Escola Nova significou um processo de remodelação das instituições escolares. As classes experimentais, constituíram, acima de tudo, como diria Anísio Teixeira, "uma lição de "liberdade pedagógica", lição que, guardadas as devidas proporções, permanece nos dias de hoje dentro dos Colégios de Aplicação.

\section{O professor escolhe seu lápis quando encontra os personagens da cena}

\section{Os diferentes lápis}

Por envolver o ideário dos sujeitos e constituir-se por concepções abrangentes das representações em relação à escola e à sociedade, o estudo sobre as representações de práticas democráticas nos Colégios de Aplicação foi de natureza qualitativa, já que se sustenta nas características apontadas por Lüdke e André (1996, p. 11) de tomar "o ambiente natural como sua fonte e tê-lo como seu principal instrumento". Concomitantemente às observações do cotidiano escolar nos Colégios pesquisados foram distribuídos questionários e realizadas entrevistas semi-estruturadas ${ }^{5}$ que serviram de base de sustentação para a análise dos dados.

Mesmo havendo representações de desejo, medo e insegurança podemos observar expressões no que diz respeito à temática pesquisada, quando Maria Augusta, uma professora entrevistada, declara que:

a democratização é linda para se ouvir na palestra mas no dia seguinte, no dia-a-dia é muito difícil. A escola democrática não é aquela que fica dizendo [...] lava os dentes, limpa a mãozinha [...] é pior [...] cria mais defasagens. Pois a escola de elite já está nessa hora fazendo reflexões sociais e humanitárias e intelectuais e assim nós vamos regredir, pois antes nós fazíamos reflexões nesse nivel de intelectualidade e não de atitudes corriqueiras e banais.

Mas essa representação de distanciamento e afastamento com os novos alunos não fica sozinha, ela encontra uma con-

\footnotetext{
${ }^{4} \mathrm{~A}$ influência das comprehensive schools americanas estão vinculadas a concepção educacional de Anísio Teixeira enquanto que Gildásio Amado propõe uma tendência mais francesa de concepção de ensino como demonstra na Exposição de Motivos do Diretor do Ensino Secundário ao Sr. Ministro da Educação e Cultura (AMADO, G. Classes experimentais. Revista Brasileira de Estudos Pedagógicos, Rio de Janeiro, v. 30, n. 72, p. 73-83, out./dez. 1958).

${ }^{5}$ Quanto às entrevistas e aos questionários procuramos preservar o anonimato dos professores dando-lhes nomes fictícios e não apontando para qual escola pois não havia intencionalidade de análise comparativa entre as instituições.
} 
trapartida quando a Prof. Jaqueline diz: Com a nova clientela criou-se um ambiente mais rico, com pessoas que trouxeram par dentro da escola sua cultura de bairro, de família, de amigos, diferente daqueles que conviviam somente com os alunos selecionados em vários níveis. Esse aspecto favoreceu uma nova dinâmica. Que é mais árduo, que é mais difícil, que é mais trabalhoso, é sem dúvida [...] mas que tem mais mérito [...] ah isso tem!

Esses depoimentos seguidos de suas representações demonstraram que se a escola não abre para o confronto, não haverá confronto de discursos para se valorizar a cultura acadêmica e entender as representações dos atores sociais que tecem um novo tecido escolar. Propositadamente, demonstramos essas falas para evidenciar as contradições existentes nos Colégios. As diversas respostas das entrevistas demonstraram o relacionamento dos indivíduos com o espaço socializador carregado de significação (ORLANDI, 1999, grifo do autor) onde o sujeito socializador reveste-se de certas percepções ou conjecturas que tentam defender seus próprios interesses, pontos de vista nas suas diferentes formas de representações sociais. Neste percurso, definimos que aconteceram movimentos de busca de construção de encontro com a finalidade dos CAps e também movimentos que denunciaram desencontros.

Atualmente, os Colégios contam com um quadro docente que demonstra uma significativa qualificação na titulação, sendo constantes o esforço e a dedicação dos professores na realização de cursos de Mestrado e Doutorado. Além daqueles docentes que já obtiveram o grau de Mestre ou Doutor, vários outros, no momento, estão matriculados em cursos de Pós-Graduação em suas áreas específicas. A crescente capacitação do corpo docente tem contribuído para um aumento da quantidade e qualidade dos projetos de pesquisa e de extensão que vêm se desenvolvendo nas unidades, bem como para a ampliação de parcerias em projetos que envolvem outras unidades da UERJ e da UFRJ e outras instituições de excelência do país. Essa apresentação qualitativa não fala por si só mas para dar suporte a análise desenvolvida por Douglas (1998) que considera os sinais de comportamento de quem trabalha a partir das condições e relações concretas e, também as relações subjetivas como indicadores de contradições, tomadas de forma discursiva de aproximação e distanciamento das condições de cada homem, de cada grupo docente numa visão e formação de uma educação democratizante.

Entendemos quando o professor escreve que "não sobra espaço para discussões substantivas sobre si mesmos" ou quando argumenta que para manutenção de uma escola democrática, "é imprescindível entender o caráter dialógico da autonomia e do respeito entre os professores, os alunos, os funcionários, os pais e a comunidade para se ter uma abrangência de cada um como cada grupo [...] o que não está acontecendo" faz um contraste com outros argumentos que se evidenciaram ao verificar que " nossa escola compartilha há muitos anos com as lutas políticas e sociais do país, nós somos os defensores da democracia" ou pelo escrito de outro professor que lembra " a manutenção de uma classe democrática se faz com os professores que estão aqui, lutando para que seus alunos possam viver com grupos diferentes e saberes variados". 
Pensamos que dessa forma os professores não se percebem aderindo ao autoritarismo de idéias ou a atitudes emancipatórias. São discursos típicos, em dimensões locais, das forças produtivas e das forças destrutivas por uma lógica, pessoal e profissional, que harmoniza ou desagrega, segundo Habermas (1988). Eles sinalizam que os professores consideram centrais os compromissos, os laços e questões iluminadas na sua interpretação. Solicita a percepção da realidade cotidiana do grupo com o qual se vai trabalhar pois os professores revelam suas representações nas suas práticas usuais ao lidarem com os Colégios de Aplicação como espaços públicos escolares: " [...] ○ grupo heterogêneo atrapalha [...]"; "[...] abrir provocou a vivência com culturas diferentes [...]"; "[...] os alunos não vêm preparados..."; "...temos buscado mais aproximação...".(grifo nosso). Por isso, podemos dizer que, na escola, o nexo instrução-educação somente pode ser representado pelo trabalho vivente do professor na medida em que esse professor vivencia a contraditoriedade entre a sociedade e cultura. Como? Para tal a resposta de Gramsci (1998, p. 119) é clara: "pela prática social e profissional do professor que deve ser orientada pedagogicamente pela ética e estética".

Como locais de contestação e produção cultural, as escolas e os professores dos CAps incorporam representações e práticas que tanto promovem como, em certas situações, inibem o exercício da democracia escolar entre os profissionais. Foi utilizado o discurso desses professores para posicionar e constituir a maneira pela qual eles definem, mapeiam e compreendem a relação uns com os outros e com a comunidade escolar que há uma representação idealizante sobre escola democrática pois um grande número de professores pensam que " é aquela que forma um cidadão crítico". Quanto ao aspecto que denota o significado do professor democrático, buscamos ressaltar o que Rosa diz que "é preciso compreender seu papel de intelectual orgâmico (gramsciano), respeitando as diferenças dos alunos e tendo clareza e abertura para críticas." Para tanto, Benevides (1999) destaca, no entanto, que os educadores necessitam desenvolver uma linguagem programática na qual possam teorizar para as escolas, e não, sobre as escolas (grifo nosso). A dinâmica entre o que se idealiza e o que se vive revela o discurso polêmico e recupera o objeto da reflexão, isto é, o confronto de sentidos que se dá no processo de interação e na disputa de interesses, conforme aponta Orlandi (1997, p. 68). Esse processo e essa disputa revelam a importância da subjetividade no processo de conhecer o que implica em diferentes formas de compreender a educação como tarefa histórica e política. Mesmo estando sujeita a limitações: "se a educação não pudesse fazer tudo haveria motivo para falar dela, ainda mais quando se busca uma educação democrática", como define Forquin (2000, p. 183). Assim, pode-se perceber como a "democracia dá trabalho...", dito por Sandra, orientadora educacional.

Para tanto fomos analisando as dimensões das representações sociais de alguns pontos idealizados que serviram de pano de fundo à discussão de como ocorriam as práticas cotidianas de certas vivências e pudemos perceber três caminhos que se entrecruzavam, fortemente significativos, categorizados como: alteridade, poder e resistência que permitiram o mapeamento e o entendimento de aproximações e distanciamentos quanto ao objeto de estudo. 


\section{A alteridade}

A proposta de uma escola pública e experimental que considera uma nova forma de ingresso dos seus alunos rompendo com paradigmas estabelecidos desde a sua criação, trazia elementos novos, indagadores no que tange à práxis docente de ambas as escolas em tempos diferentes. A entrevista de Jaqueline ratifica a afirmativa:

[...] sabíamos que tudo ia mudar, mas estávamos preparados?[...] tinha uma perspectiva de fazer um trabaIho novo, por isso me interessou [...] mas também somos uma escola pública e de aplicação?...o que era mais importante estava na proposta de abrir mais um elo entre a sociedade como um todo e o colégio com novas propostas pedagógicas. [...] a grande base da mudança era o fato de um grupo de professores em uma Plenária assumir a educação popular como bandeira de luta: isso é ser progressista? [...] a realidade era partir de um novo ponto de entrada para construir o conhecimento. Isso era desafiante.

Constatei que alguns questionários também traziam uma impressão positiva: "[...] por uma questão de identificação ideológi$\mathrm{ca}$, eu achei que seria um projeto interessante, que a gente poderia desenvolver um bom trabalho." [...]. "Era uma proposta nova voltada para as classes populares. Havia muito encantamento."

inicial contentamento desaparece, quando Suzana aponta:

Tinha essa contradição, os valores que a proposta defendia não eram usado em toda a escola. Os CAps simplesmente aleatorizaram seus acessos. Até que gostei inicialmen- te, mas depois vi que o grupo muito heterogêneo leva a estigmas.

Por que o novo assusta? Porque há uma grande dificuldade no reconhecimento do outro. Maria Augusta confirma essa posição usando os seguintes argumentos:

É comum que isso aconteça. O CAp traz em sua memória uma história de seleção e de qualidade. Lidar com as diferenças no dia-a-dia da gente é muito difícil. Não estávamos preparados para atender aquele tipo de aluno; eram de um outro mundo, diferente dos nossos alunos.

A alteridade implica essa perplexidade do susto diante do novo sempre porque é diferente. Os professores falam de seu sentimento de estranheza diante daquela "nova" escola e das dificuldades suas e de seus colegas face a uma realidade de trabalho que lhes impunham mudanças pessoais e profissionais significativas. $\bigcirc$ que significa esse estranhamento com a "Outra" escola, a escola de todo dia e não apenas a definição de um Colégio de Aplicação distante deles mesmos? No cotidiano das escolas, as diferenças são como pasteurizadas, aplainadas, silenciadas, e o preconceito social é um forte companheiro, que vai conosco dentro de nós. As noções de diferença, de diversidade, de pluralidade sempre foram rejeitadas de alguma forma e a história dos saberes dos CAps retrata um campo de tensão onde havia o convívio com a relativa diferença social dos alunos, o professor não lidava com a diferença dos saberes trazidos pelos alunos.

$\mathrm{Na}$ vida de ambas as escolas o processo de classificação é central, afinal, "elas sempre foram classificadas como as melhores". 
A classificação divide e ordena o mundo social em grupos, em classes. "A identidade e a diferença estão estreitamente relacionadas às formas pelas quais a sociedade produz e utiliza a classificações. As classificações são sempre feitas a partir do ponto de vista da identidade" (SILVA, 2000, p. 82). Isto é, as classes nas quais os professores estão encaixando o "outro" ,o "novo" implica o gesto de hierarquizar. Esse procedimento, comum aos professores dos CAps, os aprisionam àquilo que consideram aceitável, desejável, natural e, em contrapartida, o "novo", aparece ainda para alguns como abjeto, rejeitável e antinatural. A história dos CAps, como foi apresentada, traça as escolas como tendo identidades hegemônicas e esta característica é, muitas vezes, assombrada pelo outro, sem cuja existência ela não faria sentido.

Essa representação de estranhamento do outro, de falta de identidade diz respeito ao seu papel como pesquisador e formador de professor quando o processo de identidade do professor dos CAps oscila pois é na diferença e na semelhança, segundo Silva (2000, p. 100) que "a identificação é construída a partir do reconhecimento de alguma origem em comum, ou de características que são partilhadas com outros grupos ou pessoas, ou ainda a partir de um mesmo ideal". É em cima dessa fundação com seus contornos identificatórios que Rosa apresenta em sua entrevista, uma forma de representação de aceitação ao novo, evidenciando "foi na diversidade dos alunos novos que consegui incluir recursos materiais e simbólicos para sustentar a identidade dos mesmos e dos novos."

Ainda sob o ângulo dessa nova identidade sob o eixo da alteridade foi sendo demarcado o campo de um passado que não se identifica com o presente nos Colégios, quando reafirmado em um questionário: "O CAp atendia aos alunos brilhantes com professores brilhantes, por isso que éramos um grande referencial". Chauí (1999, p. 37) demonstra que: "não existem estruturas organizacionais em abstrato. Elas se fazem e se apresentam em sujeitos concretos, que nelas escrevem parte de suas histórias de vida pessoal, e que, em co-autoria, escrevem também a história da instituição."

As representações do passado e do presente dos CAps demonstram que muitos professores vivem um passado profissional de glórias, de reconhecimento financeiro, de competência profissional, o que contrasta com a degenerescência do presente, sem que relacionem esses aspectos de um processo histórico que engendrou as políticas educacionais. É no cruzamento dos enunciados sobre o passado e o presente, expressos através da forma com que cada um atua e pensa, que está sendo construída, historicamente, a identidade de cada professor, do grupo de professores de cada escola, dos dois Colégios de Aplicação. Desta forma, o sujeito-professor atua como força constitutiva, nomeadora, fornecedora do traço característico daquele sujeito coletivo, daquelas instituições (DOUGLAS, 1998). São nessas relações de dominância que os professores estabelecem uma relação de estranhamento de sua escola, pois olham a escola que trabalham e pensam na escola que desejam. Jaqueline, doutoranda em Educação, argumenta:

Discutem-se assuntos como se fosse uma escola normal mas tem que se levar em conta o fator primordial que é o licenciando. Mais do que ter a preocupação de formar cidadãos é formar bons professores, é 
formar licenciandos. E os futuros professores têm que formar bons cidadãos. A escola pública precisa de bons professores. A preocupação maior tem que ser a formação de bons professores.

Isto é, alguns educadores legitimam as escolas como esferas públicas democráticas, como lugares que oferecem um serviço público essencial na formação de professores e na construção da cidadãos críticos ativos (NÓVOA, 1998). O embate desses pontos pode ser chamado de mudança de paradigma. Mesmo que os CAps tenham se proposto a mudanças começando com o processo de acesso dos alunos de forma diferenciada e depois com o da tentativa de permanência dos alunos para atender aqueles que já estão na escola sem utilizar a seletividade exclusiva, os professores que trabalham demonstram que ainda não colocaram como centro profissional uma política pedagógica e curricular de uma nova identidade. Eles ainda não souberam estimular, em matéria do novo, do outro, da sua nova identidade mais democrática, "a obrigação de ir além do conhecido e do assentado, do consensual e do assegurado, para o impensado e arriscado, o inexplorado e o ambíguo para que torne difícil o retorno do eu do nós idêntico." (SILVA, 2000, p.100).

Afinal, os Colégios de Aplicação não são um centro de experimentação, de pesquisa e extensão? Por que não multiplicam, proliferam e disseminam uma filosofia da diferença - a diferença do múltiplo e não do diverso? Acreditamos que assim os professores não estranhariam tanto o "outro". $O$ outro cultural é sempre um problema, pois coloca em xeque permanente a própria identidade da escola. A questão da alteridade, da identidade, da diferença e do outro estão ligados a representações que têm estreitas conexões com o poder, isto é, estas questões seriam tratadas como questões políticas e de poder, na esfera profissional.

\section{poder em suas diferentes atuações}

Até que ponto os professores estão usando o poder para emancipar ou conservar atitudes que imobilizam as novas propostas educacionais? Ainda analisando os dados da pesquisa, pinçamos algumas falas no que se refere a categoria do poder: "[...] dificuldade em aceitação de alunos com perfil diferente do padrão a que estava acostumado, dificuldade em trabalhar pedagogicamente a diferença."

"[...] já que o professor quer ser democrático numa postura de ouvir todos e atender a todos, ele tem que saber fazer." (grifo nosso).

O princípio da igualdade como pressuposto democrático, pode ser uma premissa falsa, uma vez que a democracia não se dá em abstrato, mas nas sociedades concretas, com seus antagonismos de classe e todo o jogo de interesses representado por estas classes. Neste sentido, é instigante o pensamento de Touraine (1996, p. 188) que:

"[...] a democracia apenas será possível quando cada um vier a reconhecer no outro, como em si mesmo, uma combinação de universalismo com particularismo: fazer descer a democracia do céu aos princípios da terra onde se chocam interesses."

Abordar as relações entre estado, sociedade e escola, em particular nos Colégios 
de Aplicação, auxilia na compreensão do assunto em sua dimensão mais micro e cotidiana. Esta questão é dita pelo discurso de alguns professores, em duas entrevistas:

"Há falta de 'entusiasmo' do Corpo Docente neste momento histórico." Maior concentração no conceito básico: Educar para quê? Quem? E em que medida? [...] Dentro do sistema que existe na nossa sociedade é uma farsa pensar em democracia. Dentro da escola também é uma farsa, toda a escola deveria ser pública e um sistema que aceita a quantidade de escolas privadas que nós temos, é reforçar a contradição de não querer dar oportunidade para todos.

Os profissionais da educação, partindo do pressuposto defendido pelo prof. Francisco de Oliveira (1991, p. 48), de que "nas condições concretas do Brasil, não pode haver método democrático sem a ampliação e a consolidação de uma esfera públi$\mathrm{ca}^{\prime \prime}$, e de que, a formação de uma esfera pública democrática no Brasil se constituirá com a conjugação de três movimentos, a saber, "o da formação de uma opinião pública, o da capacidade de pactar das classes sociais e a reforma do sistema político" (OLIVEIRA, 1998), pelo menos em aspectos de ampliação de esfera pública e educação os professores dos CAps ainda mantêm discussões sobre esses preceitos de luta de poderes, apontado por Mariana:

$\bigcirc$ "processo de democratização da escola" deveria ser tema de um fórum permanente de debates que incluísse toda a comunidade escolar. Infelizmente ainda permanece no CAp uma cultura de valorização da elitização em detrimento da de- mocratização; é necessário mudar rapidamente pois o cotidiano está nos "atropelando" e o sentimento de perplexidade pode estar instalado entre nós.

Mesmo assim, considerando que são condicionantes hoje, para o exercício do jogo democrático, a ampliação e a consolidação da educação democrática ainda não se conseguiu o espaço reivindicatório e dialógico da população docente nas escolas. No caminho desta lógica a contradição existente e a influência do liberalismo na sociedade e na escola é reforçada por uma visão um pouco maniqueísta, quando Patrícia completa:

Não sei o que acontece mas sempre na escola particular tudo corre bem e organizado, lá dá certo [...] que falta um corpo docente com mais ação e menos conversação [...]. A competitividade é saudável na medida em que os nossos alunos são apontados como os melhores no vestibular.

Esta pode ser uma forma de inculcação do projeto neoliberal hoje imposto à sociedade brasileira, segundo o qual torna-se necessário que todos se convençam, que "o público agora é o centro de todo o mal; o privado é o centro de tudo o que é bom", apontado por Apple (1995, p. 185). É o discurso da qualidade total, da competitividade, da livre iniciativa, da competência gerencial, que esconde, o que muito bem nos revela Silva (1996, p.19-20), "a natureza essencialmente política da configuração educacional existente." Para buscar a manutenção da democratização escolar, os professores reivindicam, num ângulo democrático, melhores condições de trabalho e não 
meramente de melhores salários, que:

[...] para as escolas serem mais democráticas penso que é necessário haver contratação de professores de 40 horas aqui e em outras escolas para que possam poder saber e poder fazer um bom trabaIho, em horário integral para trabaIhar com os alunos, fazer pesquisa e projetos de extensão [...]o professor "auleiro" inviabiliza qualquer pessoa a participar de reuniões para refletir sobre a Educação, como é apresentado por Paula.

Desta forma, parece que há um grupo de professores que está aprendendo e construindo um discurso da associação pública e responsiva. Estes discursos buscam recuperar a idéia da democracia crítica escolar, como um movimento social que apóia a liberdade individual e a justiça social. Além disso, "encarar as escolas como esferas públicas diferentemente que hoje se encara a força das escolas privadas", segundo Patrícia, que foi vice-diretora durante quatro anos, fornece uma fundamentação para defendê-las, juntamente com formas progressistas de pedagogia e trabalho docente, como instituições e práticas essenciais desempenhando um serviço público importante.

Além da luta pela imposição do poder da mesma escola, da escola que se fundamenta na classificação da excelência pelo atendimento aos selecionados, fica explícita a voz de uma corrente da classe média que não quer perder o poder de ser e ter um ensino de qualidade num colégio privilegiado por ser público e de qualidade com memória de luta política e projeção social. Neste caso, as classes médias assumem as funções de "intermediação sem mediação" das demandas e interesses mais difusos da totalidade da sociedade, praticando o que Oliveira (1999) chama de uma espécie de "ventriloquismo", transformando-se em "articuladoras e tradutoras simultâneas da razão de uma classe diferente da qual pertence, parte para uma razão do Estado e das razões privadas". Nessa mesma linha de pensamento sobre para quem e para que classe social é identificada a escolaridade dos Colégios de Aplicação, há discursos emancipatórios que declaram essa luta de poder, segundo Rosa:

Se não fosse o CAp, com certeza o Geraldo ainda estaria como ajudante de jornaleiro. Ele, hoje, é um profissional que até já apresentou trabalho no Japão (riso de felicidade...) Ele encontrou um chão fecundo e público para colocar sua cabeça fecunda, de tanto que ele lia lá na banca. Ele já foi longe e vai mais ainda. $O$ papel da escola pública é se abrir para o conhecimento e abrir para abrir a vida de outros [...]

Mesmo assim, o testemunho desses professores certamente sofreria uma mudança qualitativa, se demonstrassem aos seus pares que a luta pela melhoria das condições materiais da existência e pela democratização das oportunidades que exige, por parte daqueles que a desejam, "jamais transformarem ou entenderem esta como uma luta singular, individual [...] e por isso, estar sempre ao lado de seus companheiros desafiando-os e também os órgãos de sua categoria para que dêem o bom combate" (FREIRE, 1995, p.13-14).

Como afirma Paulo, que traz uma experiência profissional de ex-professor de escola municipal: 
Você insiste em falar sobre democracia, escola e situação do CAp. Quer democracia? Falta democracia na saúde, o pobre, o menos favorecido morre. Há muitas desigualdades em termos de atendimento e qualidade. Não quero falar mas estou defendendo o sistema socialista de política para educação e para a saúde. Na saúde você morre sem dinheiro. Na educação você morre em outras áreas, em outras situações, em outras práticas. Você morre no intelecto, no sentimento de viver vivido.

Nestes discursos concebe-se a escolarização como um instrumento de luta política em favor das mudanças ou estratificações sociais e nisso está implícito o papel do professor, em sua prática escolar de democratizar o saber à maioria da população. Desta forma, pensar a escola democraticamente envolve não apenas a questão essencial que é a de acesso de todos a ela, mas também na sua permanência, com uma escola de conteúdo novo e de boa qualidade, construída com as diversas camadas dos seus integrantes e não excluir os que estão nela, como até agora tem sido, segundo Benevides (1999). Assim, é preciso entender a "escola não apenas como reprodutora, inculcadora ou transformadora social, mas como parte integrante do movimento da contradição nela existente, visualizando a possibilidade de um saber escolar para além de um saber arbitrário, como um saber objetivo subjetivado", segundo Silva (1996, p. 122).

Voltamos o olhar para o conservadorismo e a manutenção, o que chama a atenção na maioria dos depoimentos é a presen- ça neles de uma tendência "de repetir o conhecido, que tende a impregnar a vida humana em sua forma de ser e de viver." (MADEIRA, 1998). É onde Suzana mistura o seu eu pessoal com o seu eu profissional e se mantém fechada para alguns aspectos de mudança social e institucional. Ela afirma que

a escola ainda mantém muitas contradições isso dá um pouco de medo, fica difícil - precisa saber fechar os conteúdos de forma mais amarrada. Antes nós fazíamos muitos trabalhos mais elaborados... eu tenho até hoje trabalhos feitos pelos meus alunos, pelos licenciandos e pelos filhos [...] eram de outro formato.

Ainda na linha da argumentação de poderes internos sobre práticas e metodologias, Marcos argumenta que, apesar de estar na escola somente há quatro anos, o motivo, por exemplo, da preferência de muitos professores para conservar a manutenção da seletividade e a escola "como era antes" está no fato de "pelo colégio ser mais tradicional implica mais segurança". Isto é, arremata sua fala com a conclusão: "de fato sou bastante moderno e conservador ao mesmo tempo, gosto de inovar em métodos pedagógicos, mas não gosto de inovar em situações que possam provocar desequilíbrios". No entanto, é importante constatar que alguns profissionais conseguem não só identificar, mas também analisar e até mesmo buscar meios para alterar essa tendência. $O$ contraponto emerge na fala de Mariana :

só trabalhando com grupos heterogêneos, com culturas diferentes, com vivências diversas que podemos situar o planejamento, pensar em estratégias, escolher a linha condutora que vise a um ambiente 
de aprendizado com o contato com mundos diferentes, sem pensar em desigualdades, mas pensando em confronto e dissenso.

No centro destas posições está a necessidade de desenvolver modos de investigação que examinem a história das Escolas de Aplicação como experiência moldada, vivida e tolerada dentro delas, mas também como certos aparatos de poder produzem formas de conhecimento que legitimam um tipo particular de verdade e estilo de vida. O poder, neste caso, como salienta Foucault (1992, p. 82), "não mistifica ou distorce simplesmente. Seu impacto mais perigoso é sua relação definitiva com a verdade, os efeitos de verdade que ele produz".

Um outro aspecto a ser ressaltado no eixo da discussão do poder envolve a falta de definição e de reconhecimento por parte das universidades, nas quais estão inseridos os Colégios de Aplicação, como ficou evidenciado em alguns questionários sobre o que poderia vir a representar esse poder de colocar a figura maior fora de seu espaço profissional como algo menor e distante:

- Para resolver qualquer coisa mais séria é preciso ir até a universidade.

- Preciso conversar com os professores da universidade.

Nessa ótica, o poder é colocado num espaço plenamente visível, destacado em sua centralidade. Dessa forma, parece que o poder está no órgão maior, que é a universidade, representante maior do local de trabalho onde o poder está concentrado. Assim, tentamos saber como esses professores imaginam uma relação diferente entre eles e a chamada universidade. As respostas foram imprecisas:
- O professor do CAp precisa ser mais valorizado.

- Enquanto não se valorizar a Educação Básica, não teremos valor até mesmo dentro da universidade. professor do Ensino Fundamental e Médio tem um lugar diferente na universidade, isso é pouco democrático.

Estas representações remetem a questões levantadas por Foucault de que não há relação de poder sem constituição correlata com o campo de saber, nem saber que não suponha e não constitua, ao mesmo tempo, relações de poder pois "há a possibilidade tanto de vigiar quanto de constituir, sobre aqueles que vigia, a respeito deles, um saber ". (FOUCAULT, 1973, p. 70, grifo nosso).

O CAp aparece como escola abandonada pelo "pai fundador", a universidade, que não protege, não intermedia, portanto não The confere nenhuma importância, acarretando-Ihe baixa auto-estima. A situação fica reforçada pela luta de uma nova identidade marcada pela UERJ e ainda na luta da UFRJ que acaba não oferecendo reconhecimento àqueles professores da Educação Básica.

O colégio começou com psicólogos, especialistas em psicomotricidade [...] foi crescendo e foi se perdendo [...] Ele não é independente, ele é preso à universidade [...] assim todos os fatores fizeram com que ele (colégio) tivesse a sensação de que é impotente [...] mas como sou forte, gosto da Educação Matemática [...] vou desenhar retas de ponto a ponto, participando e lutando [...].

Nessa luta pela recuperação da autoestima e superação da falta, do não feito, 
do desejo, do incompleto, importa "contarmos com os movimentos instituintes com que os insatisfeitos buscam instalar caminhos de emancipação na sociedade e na escola" (LINHARES, 2000, p.11). Nesse momento de crise escolar, a hegemonia da luta por melhores condições em todos os aspectos internos e externos aos muros da universidade pode ser de grande valia, para os professores da Educação Básica, uma vez que poderão dentro do processo escolar libertar-se das amarras institucionais, como diz Marcos, "quero saber quando que a universidade vem aprender conosco e ver como nós fazemos milagres com essa falta de recursos com que nós convivemos".

É nesse lugar, onde a universidade permanece surda, que parece rondar o perigo mais grave, uma vez que o abandono indiscriminado ou provoca morte lenta, ou conduz à mendicância de uma adoção a qualquer preço. Os professores precisam se engajar em lutas contra-hegemônicas para saírem da esfera da circularidade dos "saberes maiores", do saber da universidade e dos professores que lá atuam, do saber dos Colégios de Aplicação com seus atores coadjuvantes e dos saberes dos alunos com seus pseudo-saberes, onde o regime dos saberes são produzidos, legitimados e distribuídos. Há, também, um poder instituído na universidade que não valoriza, o poder da Licenciatura e da Educação Básica. Isto é salientado por diversos discursos que apontam para a configuração da materialidade linguística no interior da ideologia de poder. Esta representação de desvalorização de espaços é ressaltada por Mariana:

Veja só o Cap sempre ficou situado em prédios que seriam hospitais [...] não dá para circular como escola [...] na minha opinião não gosto de chamar isso aqui de definitivo como alguns o chamam [...] para mim falta espaço e sobra escola [...] a Universidade hoje fala de reserva de vaga, mas deveria é valorizar o trabalho do CAp, oferecendo um lugar que pudéssemos ter espaços para pesquisa, para os alunos se sentirem mais à vontade, não num lugar tão apertado, parece que precisamos ter controle de tudo, todos juntos se olhando o tempo todo.

De qualquer forma há uma ressalva de Rosa, profissional atuante em movimentos sociais, que representa a luta de poder em relação aos CAps quando diz:

[...] a universidade não quer saber de nos atender... há quantos anos temos lutado por um espaço só nosso? [...] isso aqui é emprestado e favelizado. Não consigo acreditar que não há espaço para os professores terem suas salas de estudo, não há salas para departamentos se reunirem [...] somos um grupo porque queremos pois espaço não há.

Sem dúvida essas representações sobre a falta, o reconhecimento, a valorização dos diferentes saberes, da circularidade para os atores da escola remetem ao pensamento de Foucault (1988, p. 27) nos estudos sobre a arqueologia que aponta para o deslocamento dos saberes e poderes, sobre controle e vigilância pois "essa forma de controle pode estar vinculada a uma forma de dominação e ocultação, onde a função simbólica da pouca valorização" para com os espaços institucionais exerce a pouca valorização dos sujeitos-educadores dos Colégios. Dentro desse quadro de lutas ocorre a abertura da construção de espaços físicos e simbólicos que façam esses Colégios figurarem como espaços desejados. 


\section{Permanecendo algumas resistências}

Ambas as escolas demonstravam a existência de um processo de democratização em constantes transformações internas numa perspectiva de experiência democrática. Embora o processo de resistência tenha aparecido em alguns pontos que convergiram em ambas as escolas quanto à necessidade de se rever o currículo, à falta de um projeto político-pedagógico e ao processo de avaliação que envolve o jubilamento.

No entanto, em algumas falas, às vezes das mesmas pessoas, aparece claramente a resistência, como foco do discurso da autonomia, "eu fecho a minha porta, dentro da minha sala, eu faço aquilo que eu achar melhor". As palavras desse professor parecem desenhar um poder aniquilador, aniquilador de qualquer reação. No entanto, ainda é reforçada pelo discurso de Rosa, que destaca a história, que" [...] quando houve a mudança na escola foi uma grita geral: jornais, alunos e pais. Tivemos uma discussão muito séria e resolvemos mostrar o quanto sabíamos, agora falta colocar no papel [...] os professores ainda resistem". Mas é nas brechas do movimento da resistência dessa luta pela revisão curricular que Paula faz sua fala apontando para a temática:

para acelerar ou manter a democratização do colégio precisamos rever o currículo como forma de integração com todos os segmentos e departamentos [...] quero essa escola dizendo para o que veio... - currículo passa pela ideologia, e a escola precisa identificar e desvelar os componentes ideológicos do conhecimento escolar que a classe dominante utiliza para a manutenção dos privilégios.

Destaca-se, desta forma, frente a esses discursos que há resistências que impedem que o grupo dos professores pense de uma forma coletiva a construção do conhecimento escolar. Remetem a representação que demonstra que a determinação de um conhecimento escolar implica numa análise interpretativa e crítica, tanto da cultura dominante, quanto da cultura popular. Se os professores reclamam da falta de uma revisão curricular como um dos componentes dos processos da formação de uma escola mais democrática, é porque ainda estão operando numa perspectiva fragmentadora, própria de uma concepção positivista que deu sustentação ao desenvolvimento da ciência, à organização da produção e à estrutura social que se quer ver transformada. Se se pretende inscrever os Colégios de Aplicação na ordem das mudanças institucionais exigidas pelo atual momento histórico, é preciso romper com as resistências. Acreditamos que os movimentos dessas escolas exigiriam pensar em voltarem-se para a intencionalidade política que articula a ação educativa a um projeto histórico e, repensarem um paradigma epistêmico-conceitual que orientarão as práticas pedagógicas, conferindo coerência interna à proposta, articulando teoria e prática. Poderia dizer que seria um currículo comprometido em (re)estruturar os Colégios em articulações coerentes, imprimindo-lhes uma unidade interna que se expressa no modo de conceber, organizar e desenvolver as formas de orientar o processo metodológico do ensino; nas relações amplas e complexas do cotidiano escolar responsáveis pelas aprendizagens mais significativas, uma vez que consolidam valores 
e desenvolvem cultura, pois não se trata apenas de selecionar conteúdos, porque o tipo de relacionamento entre educadores e educandos - portanto, a democratização do ensino em sua face de maior simetria entre os agentes da educação - também se baseia na forma com que se realiza a seleção." (GADOTTI, 1999, p. 17).

Ao pensar na constatação de que há discursos que alertam para a falta de um projeto político-pedagógico registrado oficialmente entendemos que os CAps são escolas públicas e é oportuno reafirmá-las como categoria do espaço público em sua totalidade no sistema educacional para servir cada vez melhor a sociedade numa perspectiva não conclusiva: há muito que fazer, mudar e construir. Mas encontra-se uma forte resistência por alguns professores que desejam justificar alguns obstáculos para as formas de democratizar a escola e outros que procuram defender a sua elaboração:

$O$ que pode ser considerado mais negativo aqui na escola é a falta de um projeto político-pedagógico para dar uma unidade de conduta para o atendimento aos nossos alunos. Eu vivo reclamando mas quando vamos elaborar nosso projeto para ser oficialmente reconhecido no Conselho Universitário?

A falta do projeto não iria prejudicar em nada nossa função de colégio de Aplicação porque poderíamos mostrar mais as características de escola experimental e escola de formadores de professores. O CAp é essa fluidez não gosta de se sentir amarrado, mas temos que pensar que faz falta até para os institutos de origem fazerem suas práticas de ensino aqui. Todos os alunos adoram fazer estágio no colégio mas faz falta para eles terem uma visão desse todo que é a escola, senão reforçam-se as especialidades de cada disciplina e não se dá orientação teórica do todo da escola.

que demonstram os discursos dos professores dos CAps é que, na maioria das vezes, a ponte que liga o que se faz e o que se deseja fazer se rompe e tudo fica no nível do desejável. Um clima de insatisfação, dúvida, medo e resistência alastra-se entre os educadores e a tendência tem sido buscar em elementos soltos a justificativa do não-realizado. Esses argumentos parecem aliviar a frustração dos professores dos Colégios, até porque são justificativas procedentes, mas aos poucos e através da evidência mais viva que a escola possui - a função dos CAps e o desejo de formar cidadão crítico - volta a indicar por alguma (re)construção que pode e deve ser gerada na própria escola, atenuando ou mesmo transpondo as interferências das resistências de reclamação e na não realização do projeto nas escolas. Desta forma, encontram-se dentro de ambos os Colégios propostas pedagógicas soltas, diretrizes que regem as escolas, repletas de nuanças democráticas e no fluxo do poder das diversas esferas da organização pedagógica e administrativa em geral, ações antidemocráticas, tais como processo de avaliação, departamentos fechados em si, falta de interdiciplinaridade numa escola experimental e por vezes uma estrutura que não quer mudar. Não são expectativas de um sujeito isolado, mas de uma comunidade de sujeitos que se orientam por significados idên- 
ticos reflexivamente referidos à validez intersubjetiva dos compromissos do agir solidário, de acordo com Habermas (1988). Isto é, os sujeitos devem entender-se entre eles sobre os compromissos que juntos assumem. Desta maneira

a intencionalidade política traduzida em proposta pedagógica não é apenas constatativa ou descritiva, mas é constitutiva do ser da escola, que se define, assim, em sua especificidade e identidade, por se fazer elucidativa da vontade coletiva e relevante para os fins a que oferece as condições de se cumprirem. (BOURDIEU, 1996, p. 93).

Assim terão que enfrentar o imbricamento na proposta nas duas dimensões do instituinte e do instituído: a dimensão éticopolítica da natureza intersubjetiva da formação da vontade coletiva e da coordenação e da condução da atuação solidária. Para que essa intencionalidade éticopolítica não se esgote no plano do voluntarismo faz-se necessário que os professores consigam desatar suas amarras e pensar nas suas resistências quanto ao que desejam para si e para a escola: nas relações intersubjetivas, na gestão democrática da escola, na disposição material dos lugares, coisas e tempos, no pleno aproveitamento das virtualidades dos recursos e metodologias disponíveis e, sobretudo, na mediação da docência, por onde se cumpre a forma escolar de sistematização das aprendizagens necessárias à cidadania de todos, solidária, responsável, construtiva de novas formas de convívio e interação.

Ficou evidenciado que ainda existe um fator identificatório que implica na forma de tornar a escola pouco inclusiva. Fala- se sobre democracia e alternância de poder para o fortalecimento de práticas democráticas mas ainda não se reformulou um processo de exclusão da "escola de excelência e de qualidade", isto é, há no interior do processo de avaliação uma resistência ainda perversa, que é a jubilação escolar. Existe um grupo de professores que defende que não existe democracia escolar e que a escola é um lugar de ensino de conteúdos programáticos, o lugar do saber escolar, que é selecionado e transmitido em função de interesses específicos. Essa legitimação se dá através do exercício de resistência sob a forma de violência simbólica, "utilizando os sistemas de representações e não a força da imposição, para assumir seu papel mantenedor das relações de força." (BOURDIEU, 1996, p. 43). Assim, a seleção do saber e sua forma de transmissão fazem-se de acordo com os interesses de grupos, em função de sua capacidade de manter a dominação, processo através do qual será eliminado todo - saber que versa sobre essa dominação ou que venha a alterá-la ou ameaçá-la. É deste modo que a escola favorece os já favorecidos, excluindo e desvalorizando os demais. Assim, de acordo com a corrente reprodutivista, o sistema de ensino exerce as funções de reprodução de cultura e a reprodução das classes sociais, afirmado por alguns professores nos questionários:

Bem próxima a essa linha de pensamento, encontra-se a teoria de Baudelot e Establet (1971) que visualiza a escola como aparelho ideológico a serviço da classe burguesa na luta ideológica contra a classe popular e proletária. Apoiado nessa linha filosófica educacional, há um discurso de um professor do CAp que ressalta que a escola deve atender "as pessoas mais bem 
preparadas e com isso poder preparar bem o licenciando". Desta forma a escola fica fechada em si mesma e não se constitui espaço de luta de classe, o que é declarado por Baudelot e Establet (1971). Mas há o fator do alcance da contradição, na fala de Paula que conta:

Não acredito em jubilação, pois sei que muitas vezes eles só sabem o que está aqui dentro e pegam tudo daqui e usam lá fora. Acreditando nisso tive um aluno que passava o dia inteiro aqui na escola pois não tinha lugar para ele estudar em casa e aquele menino calado fez prova para o IME e passou.

Essa forma de destacar o papel da contradição na escola permite que mesmo dentro dos CAps haja discursos que podem denunciar formas reprodutoras e outras emancipadoras,

essas múltiplas formações discursivas mostram que não há coincidência entre os discursos e a ordem das coisas. Uma mesma coisa pode ter diferentes sentidos para os sujeitos. E é aí que se manifesta a relação da contradição da materialidade da língua, "da história e dos homens" (ORLANDI, 1996, p. 22).

È necessário, para um entendimento concreto da escola, analisá-la de forma dialética, abrindo espaço, também, para a categoria da contradição e da inclusão e não apenas para a reprodução. Não pode ser desconsiderada a contradição que o próprio sistema coloca na sua evolução. Ainda ressaltando o papel de uma escola plural e inclusiva encontra-se um questionamento de Paula, que aponta: "o que se tem feito e o que faz o professor, dentro das suas possibi- lidades, para modificar o quadro de jubilamento dos CAps?" (fala com determinação pois sabe que ambas as escolas adotam o processo de jubilação para alunos).

Nos discursos dos professores há uma forte tendência para entender e de não aceitar a distância entre o universo cultural e a cultura de origem dos alunos, tanto que na fala de Paulo fica evidente seu universo contraditório de entender a escola quando denuncia e defende: "sempre são os mesmos que são jubilados, os filhos dos funcionários, os menos favorecidos das classes subalternas, os que moram longe [...] a nossa escola ainda fica em certa posição de julgamento e não de compreensão."

Mas há ainda professores que confirmam uma prática de excelência pela não aceitação de uma escola mais democrática, quando se expressam como Marcos adverte : "não tem jeito, precisamos ficar com aqueles que desejam ficar na escola Tantos desejam ficar aqui e, depois, quem tem que ficar aqui são os licenciandos que precisam aprender muito."

A propósito, é nesse particular que cabe ênfase ao trabalho do professor cujo objetivo deve ser a socialização do saber cultural como forma de superar as reprovações, os jubilamentos. Há necessidade de serem revistos os padrões de excelência utilizados no trabalho pedagógico, com base nos valores e padrões das diversas classes sociais que estão inseridas na escola. A prática escolar deve ser questionada e o jubilamento visto, também, como decorrente das características internas da escola, naquilo que lhe é específico, sem, obviamente, excluir seus objetivos educacionais, sociais, políticos e culturais. Na análise que 
efetuamos ficou evidente nas representações dos professores a alta seletividade ainda existente nas escolas, isto é, não basta apontar ou reclamar dos alunos, pois as contradições representadas pelos professores evidenciam a necessidade de mais reflexão e debatequanto ao entendimento e posicionamento frente ao processo de jubilamento nas escolas. A resistência coletiva também pode acarretar um certo medo e provocar distanciamentos entre os professores, como Rosa afirma:

não dá para jubilar o aluno que se esforça muito, que estuda, que quer participar, ele pelo menos poderia ficar até terminar o Ensino Fundamental e depois ser encaminhado para uma escola técnica onde ele poderia ter logo um trabalho em um período pequeno de estudo e entrar no mercado de trabalho.Alguns professores deixaram de falar comigo, porque num Conselho de Classe, queriam jubilar um aluno que era considerado desinteressado em algumas matérias e eu tive a coragem de enfrentar a minha própria classe [...] penso que há determinadas coisas que ensino não faz sentido para ele e outros, sabe [...] estou falando da inclusão [...] e a repetência seria evitada se os alunos tivessem um outro tipo de aula, de professor.

As formas de jubilamento das duas escolas ocorrem de forma diferente: o CAp da UERJ admite uma reprovação em cada série do Ensino Fundamental, enquanto que o CAp da UFRJ considera que o discente só poderá ser reprovado uma vez no Ensino Fundamental e uma vez no Ensino Médio. Apesar da manutenção do jubilamento nas duas escolas existe um grupo de professores que denunciou nas respostas dos questionários, uma acentuada preocupação com essa situação. Há um grupo de professores que não desanimou; ao contrário, está buscando alternativas de solução para os problemas de ordem técnico-pedagógica, que se façam mais acompanhamentos aos alunos e que se efetuem mais trabalhos interdisciplinares que poderão romper com o desânimo e a acomodação.

As escolas que fazem uso destes meios para conseguir a "excelência" ou a "manutenção de ficar só quem está interessado" demonstram que os professores ainda tendem a reproduzir as relações de poder e de resistência a mudanças presentes na sociedade. "O recurso da jubilação como papel disciplinador e seletivo contribui para a exacerbação do autoritarismo, a opressão do educando e, consequentemente, para o cercear o seu desenvolvimento intelectual" (GONDRA, 1997, p. 15). Porque a dicotomia de favorecer a alguns o acesso e o aprofundamento do saber e a outros a estagnação e o esvaziamento denuncia que a jubilação é um dos mecanismos que está a serviço de uma pedagogia que traduz a divisão social dentro da escola. $\bigcirc$ uso da jubilação denuncia os colégios como escolas dualistas, corporificando o discurso liberal de seleção dos mais aptos, dos mais capazes e contrárias aos princípios democratizantes, inscrevendo, definitivamente, a prática como materialização do pensamento liberal. Por esse viés, o conceito original de Colégio de Aplicação, enquanto espaço de experimentação e de criação, fica profundamente comprometido, na medida em que reproduz a atitude da dominação, da exclusão, de modo a reforçar o afastamento de certos alunos numa concepção tradicional de escola. 


\section{Com um lápis e um} papel...cria-se um novo texto: representações de práticas democráticas em Colégios de Aplicação

Embora alguns professores declarem-se "meio perdidos, porque as pessoas fazem o que querem e não sabem diferenciar trabalho de grupo com liberdade de cátedra [...]" vários deles compreendem que há um imbricamento crescente entre a dimensão social e a individual, tanto na formatação da escola pública, quanto na construção de regras do jogo democrático, que se fazem presentes no dia-a-dia das relações de cada sujeito social. Os Colégios de Aplicação ao apreenderem, adaptarem e traduzirem estas representações, realizam um tipo de acomodação e de combinação, entre um conjunto de docentes com seus elementos contraditórios. Como afirma Jodelet (1989, p. 188), as representações sociais constituem-se numa "forma de conhecimento socialmente elaborado e partilhado, tendo um objetivo prático e concorrendo à construção de uma realidade comum a um conjunto social."

Aqui, tem-se, talvez, a maior riqueza da abordagem desses grupos dos Colégios que se envolvem em posições de tensão, com dimensões distintas sobre um mesmo objeto. Destacamos alguns depoimentos que enfatizam a democratização escolar:

- Já disse antes que a sociedade precisa ser mais democrática. Em relação à política educacional, pode-se dizer que o vírus neoliberalizante não nos contagiou de todo. Muito pelo contrário, a am- pliação de oportunidades educacionais, para mim, é um dos fatores mais importantes para a reducão das desigualdades. Você quer mais do que este campo fertil do que o Colégio de Aplicação!

- Nossa escola cresceu. Em primeiro lugar ofereceu livre acesso para os alunos e em segundo lugar as decisões são discutidas por toda a escola.

- Como há um corpo docente qualificado com estímulo para a docência, pesquisa e extensão, há uma vontade de aprimoramento dos docentes. Nós temos muitas mudanças que já estão em curso e uma delas é a preocupação com a inclusão, com a formação do aluno. Há alunos ávidos para o conhecimento e com isso, nós estamos vivendo uma socialização de conhecimentos que a cada dia que passa reforça mais a integração de culturas. Isso implica a uma não redução de nível acadêmico.

É nessa direção de ampliação dos espaços públicos escolares que as representações de princípios como liberdade, atividade, autonomia e criatividade tomam força pois a escola e principalmente a sala de aula, são espaços do cotidiano escolar onde se deflagram elos de uma complexa cadeia de relações de poder e de dominação.

A questão da alteridade levou-nos a algumas reflexões sobre o papel do educador. Constatamos que existe de fato, uma resistência ao novo cuja complexidade apresenta múltiplas faces: o estranhamento do outro, o outro com passado e o presente do 
Colégio e o outro como o bem público tomado como privado. A pontuação do sociólogo Touraine (1994): "A humanidade cessa nas fronteiras da tribo [...]" coloca bem clara a questão do etnocentrismo, tendência que vem se apresentando persistente na "escola que nasceu para ser elite" ou "escola que é a melhor escola pública do Rio de Janeiro" ao longo de décadas. Ainda hoje convivem com a polarização: visão elitista ou visão democrática mais diferenciadora quanto à sua abrangência educacional. Há urgência de que dirijam-se os esforços no sentido de buscar, de alguma forma, o reconhecimento tardio, porém premente, do relativismo e da singularidade, essas marcas fundadoras da diversidade e da diferença que se estabelecem nos registros do social e do psíquico, fundamentais para uma leitura moderna de concepções de cultura, de ética, de estética, de vida e de morte. Como diz Bourdieu (1998): nessa conversão do pensamento, nessa ruptura com o pré-construído, nessa "revolução do olhar". O olhar do outro é constitutivo, forma o seu eu segundo a imagem do outro. Assim Silva (1999, p.33) sustenta que "[...] o outro tem para o homem o valor cativante pela antecipação que representa a imagem unitária [...]." $\bigcirc$ outro especular compõe, assim, momento decisivo no processo identificatório que é estruturante, para os Colégios, para os professores, para os alunos [...]. Uma saída para a questão da alteridade, como nos aponta Bobbio (1996) e Chauí (1999) é adotar uma linha de conduta reveladora de maior disponibilidade para o outro pelo dialogismo. No diálogo com o outro, aprende-se a apreciar a polifonia, a ouvir a diversidade das vozes. Exercita-se uma linguagem que amplia os horizontes para a compreensão do que está além do saber constituído.
$\mathrm{Na}$ pesquisa vimos que categoria do poder é um fenômeno que sozinho não explica as formas de representar as aproximações ou distanciamentos para a formação de práticas democráticas escolares. Encontramos também falas dos professores, em número expressivo e em tom contundente, sobre as relações de poder que vivenciam nas escolas. A frase de Sandra que diz: "era a vontade de alguns mas não era a vontade de todos" e que ainda completou "para estar bem, ou aceita ou dança, aqui não é mais como era antigamente" traduz, ao nosso ver, essa relação de poder, presente no atendimento aos diferentes grupos sociais, a tradição conservadora e a força da Universidade frente aos Colégios. Por esse motivo a democracia precisa ser mantida como um produto inacabado, uma utopia em permanente construção, um desejo irrealizável em permanente estado de pulsão pelo seu conteúdo inconcluso. $\bigcirc$ que estas falas enfatizam é a importância da presença dos laços como elo de integração e sobrevivência do grupo, sendo que na escola pública, ela tem sido sustentada por um ideal de democracia e cidadania que se constrói sobretudo em torno de uma ilusão, de uma idéia, qual seja, da utopia da escola democrática, que se personifica, a cada momento, em torno dos professores que ali estão envolvidos. Concebem a escola como um desejo que se renova a cada dia e que certamente morrerá se concretizada como verdade única, como ressaltou Paulo: "morre na intelectualidade como morre na saúde física."

Pensando também na questão da resistência destacamos a dificuldade de se executar, escrever ou elaborar um projeto políticopedagógico, rever o curriculo e pensar sobre a jubilação, questões que ainda pername- 
cem nas escolas em estudo. Associamos a postura dos professores às dificuldades deles em trabalhar com as diferenças culturais pois antes havia a garantia da qualidade dos alunos vinculada ao poder da classe dominante. A cultura popular segundo o pensamento de Chauí (2000, p. 81) é a expressão dos dominados como um "conjunto disperso de práticas, representações e formas de consciência que possuem lógica própria:o jogo interno do conformismo, do inconformismo e da resistência [...]. É de alguma forma que a representação entre o medo e a esperança, vivida talvez mais que o possível passa não só pelo olhar mas também pela palavra e pela ação do educador. Reivindicar políticas educacionais que busquem, com urgência, como viabilizar propostas pedagógicas para a transformação e como orientar alterações que tornem mais eficazes as ações na área de formação dos professores.

Ao lado das análise críticas desenvolvidas em torno das práticas democráticas dos Colégios ocorridas nessas organizações escolares por parte de alguns docentes há uma percepção de que uma "educação democratizante" permite ao corpo docente e discente ascender a um nível elevado de assimilação da cultura da humanidade. E nesse novo colorido que se pretende alcançar, Nunes (1990, p. 29) lembra aos educadores:

[...] se nos deixarmos abater pelos insucessos e dificuldades na gestão da coisa pública, estaremos reforçando o recorrente refrão de que a mudança não é possível, de que o educador não é capaz de administrar a educação. Nossos fracassos nos ensinam e talvez um dos aspectos positivos do nosso engajamento nessa luta seja o fato de que ela nos obriga a enfrentar com dis- posição nossos limites para alargá-

los e avançar dentro deles.

Assim, com relação ao processo de construção de democratização escolar dos CAps destacamos três representações significativas : a aqueles que defendem a mudança da escola para adaptá-la a contextos sociais em transformação e democratizar o acesso ao saber, mas cuja vontade aparentemente é frágil e se limita a discurso que não passa à ação. $\bigcirc$ objetivo desse grupo é conservar o adquirido, manter o já instituído nas suas raízes de escola elitista na sua forma excludente. Estes não combatem abertamente a idéia de que a escola deva formar aceitar o maior número possível de pessoas das camadas populares, mas argumentam que "a qualidade dos alunos vai mudar e nós não seremos mais os melhores no ranking das escolas públicas".

A segunda representação está apoiada no argumento de que a educação democratizante é, ao mesmo tempo, demagógica e alienante para com as exigências acadêmicas das normas estabelecidas, vistas como "lógicas" e portanto "justas", necessárias à conservação das escolas. Alguns dos nossos companheiros ainda pensam, e não ousam dizer em voz alta, que nem todos podem ter a mesma instrução. Estes não vêem motivos pelos quais oferecer a todos uma formação de alto nível, pertinente apenas para os que farão uso dessa instrução em cargos de comando. É importante para esse grupo que os CAps sejam, em parte, um oásis e que elas continuem a funcionar como se fosse um "santuário", um lugar que ofereça "proteção" aos alunos e professores dessa "democratização inconseqüente". A renúncia às práticas democráticas re- 
tarda as mudanças. A despeito das renovações das idéias pedagógicas, o trabaIho de alguns professores evolui "lentamente" porque a relação educativa evolui obedecendo a uma trama estável e porque suas condições de trabalho e sua cultura profissional já estão transformadas em rotinas e é por isso que esse grupo de professores entende a abertura escolar para os mais diversos alunos como um desequilibrio das práticas pedagógicas.

Sem dúvida, uma terceira representação se destacou: há os professores que persistem em defender que o sistema edu-

Recebido em: 14/10/2003

Aceito para publicação: 9/11/2004 cativo beneficia-se de uma "autonomia relativa" (BOURDIEU; PASSERON, 1983) provocando situações de aprendizagem que avançam na direção do reconhecimento do outro e de sua integração na vida escolar. Exige uma políitica da diferença, na qual as demandas, culturas e relações sociais de grupos diversos sejam uma tradição histórica como parte do discurso do pluralismo cultural. Essas representações demonstram a busca de um grupo da escola para buscar na própria prática os elementos para reinventar os conteúdos, os métodos e a organização escolar, fixando sua identidade de escola modelo e experimental. 


\section{ABSTRACT}

\section{With pencil and a paper... a new context. The representations of democratic practices}

This article has the intention of study in the social representations that the teachers of the Lower School of the Colégio de Aplicação build over the democratic public school having as its research field the Colégio de Aplicação of the Federal University of Rio de Janeiro and the Colégio de Aplicação of the State University of Rio de Janeiro. The main objective of the present study was to capture the dynamics of the representation construction of a democratic school, and at the same time to search for its historical and ideological motivations and the changes it suffered along the time; and also to understand the values, the rules, the behavior, the symbols and the resistances of the lower school teachers towards the democratization process of the contemporary pedagogical practices. The lower school teachers representations about the democratic school follow the present education project that is being developed at the CAps or the one that has been already applied in another historical moment. This project in itself becomes the reference of the public, democratic and the quality school. In the crossing of the speeches were born the analytical categories: alterity, power and resistance. It was concluded that the democratic education could not be based on any notion of non-history and transcendental truth or authority. The school democracy is a tension process born by the power relationship within the institution. Among the investigated group, were encountered representations that maintain the CAps' original selective and elitization function, and therefore reinforce the social exclusion; Other representations defend a differentiated formation in line with the CAp student original social class and a third group that reinforces the possibility of the implementation of an educational project that advances in the direction of the introduction and recognition of the lower class students into the school activities and daily life.

Keywords: Colégios de Aplicação. Democratic public school. Teacher's representations of democratic practices.

\section{RESUMEN}

\section{Con un lápiz y un papel ... se crea un nuevo texto: las representaciones básicas de prácticas democráticas en los colegios de aplicación.}

Este artículo presenta una investigación a cerca de las representaciones que los profesores de la enseñanza básica de los Colegios de Aplicação da Universidade Federal do Rio de Janeiro - UFRJ y Universidade Estadural do Rio de Janeiro - UERJ construyeran sobre la escuela pública democrática. El objetivo general es el de aprender la dinamita de construcción de las representaciones a cerca de una escuela democrática, buscando verificar sus motivaciones históricas e ideológicas y los cambios que han sufrido a lo largo 
del tiempo, además de los valores, las reglas, las actitudes, los símbolos y las resistencias de los docentes frente al proceso de democratización de las prácticas pedagógicas contemporáneas. Las representaciones de los docentes sobre la escuela democrática se relacionan al proyecto educativo que se encuentra en curso en los CAps, los cuales se han desarrollado en otra coyuntura histórica,. Este proyecto se asume como una referencia de escuela pública democrática y de buena calidad académica. En el cruce de estos discursos, surgieron las categorías que son el eje al análisis de los datos: alteridad, poder y resistencia. Entonces se llegó a la conclusión de que la educación democratizadora no puede basarse en cualquier noción a-histórica y transcendente a cerca de la verdad o la autoridad. Fueron encontradas representaciones que conservan la función original, selectiva y elitista de los CAps; representaciones que defienden una formación diferenciada en acuerdo con el origen de la clase social del estudiante que ingresa a los CAPs y, finalmente, representaciones que fortalecen la posibilidad de implantación de un proyecto educativo que camine hacia el reconocimiento del alumno de los sectores populares y su integración en la vida de la escuela.

Palabras-clave: Colégios de Aplicação. Escuela pública democrática. Representaciones docentes de las prácticas democráticas.

\section{Referências bibliográficas}

ABREU, A. A. Intelectuais e guerreiros: o Colégio de Aplicação da UFRJ de 1948 a 1968. Rio de Janeiro: Ed. UFRJ, 1992.

ALTHUSSER, L. Ideologia e aparelhos ideológicos do Estado. Lisboa: Editorial Presença, 1974.

AMADO, G. Classes experimentais. Revista Brasileira de Estudos Pedagógicos, Rio de Janeiro, v. 30, n. 72, p. 73-83, out./dez. 1958.

Classes secundárias experimentais: balanço de uma experiência. Revista Brasileira de Estudos Pedagógicos, Rio de Janeiro, v. 40, n. 91, p. 90-151, jul./set. 1963.

APPLE, M. W. $\bigcirc$ que os pós-modernistas esquecem: capital cultural e conhecimento oficial. In: SILVA, T. T. et al. Neoliberalismo, qualidade total e educação. Petrópolis: Vozes, 1995.

ARENDT, H. A condição humana. 4. ed. Rio de Janeiro: Forense Universitária, 2000. Entre o passado e o futuro. 3. ed. São Paulo: Perspectiva, 2001.

BAUDELOT, C.; ESTABLET, R. A Escola capitalista. São Paulo: Cortez, 1971.

BENEVIDES, M. V. M. A cidadania ativa: referendo, plebiscito e iniciativa popular. 3. ed. São Paulo: Ática, 1999. 
. Educação para democracia. Notandum: revista semestral internacional de estudios acadêmicos, São Paulo, v. 1, n. 2, jul./dic. 1998. p. 83- 96.

BOBBIO, N. O futuro da democracia: uma defesa das regras do jogo. 5. ed. Rio de Janeiro: Paz e Terra, 1996.

Igualdade e liberdade. 3. ed. Rio de Janeiro: Ediouro, 1997.

BOLETIM DO CAp/UERJ. Rio de Janeiro, v. 1, n. 1, maio 1997.

BOURDIEU, P. Coisas ditas. São Paulo: Brasiliense, 1996.

A escola conservadora: as desigualdades frente à escola e à cultura. In:

NOGUEIRA, M. A.; CATANI, A. (Org.). Escritos de educação. Petrópolis: Vozes, 1998.

BOURDIEU, P.; PASSERON, J. C. A reprodução: elementos para uma teoria do sistema de ensino. Rio de Janeiro: Francisco Alves, 1983.

CHAUÍ, M. Conformismo e resistência: aspectos da cultura popular no Brasil. 4. ed. São Paulo: Brasiliense, 2000.

. Cultura e democracia: discurso competente e outras falas. São Paulo:

Moderna, 1999.

CUNHA, N.; ABREU, J. Classes secundárias experimentais: balanço de uma experiência. Revista Brasileira de Estudos Pedagógicos, Brasília, DF, v. 40, n. 91, p. 90-151, jul./set. 1963.

DELUIZ, N. Metodologia da pesquisa. Rio de Janeiro, 2001. Mimeografado.

DEL PRETTE, A. Pesquisa em movimentos sociais: uma análise histórica . Ciência e Cultura: revista da Sociedade Brasileira para o Progresso da Ciência, São Paulo, n. 42, p 101-116, 1993.

DOUGLAS, M. Como as instituições pensam. São Paulo: Editora da Universidade de São Paulo, 1998.

ESTABLET, R. A escola. Tempo Brasileiro, Rio de Janeiro, n. 35, 1973.

FORQUIN, J. C. Escola e cultura: as bases sociais e epistemológicas do conhecimento escolar. 3. ed. Porto Alegre: Artes Médicas, 2000.

FOUCAULT, M. Power and knowledge: selected interviews and other writings, 1972 1977. New York: Pantheon Books, 1992.

. A verdade e as formas jurídicas. Rio de Janeiro: PUC-RJ, 1973. Mimeografado. 
. Vigiar e punir: nascimento da prisão. Rio de Janeiro: Vozes, 1988.

FREIRE, P. Professora sim, tia não: cartas a quem ousa ensinar. São Paulo: Olho d'Água, 1995.

GADOTTI, M. Educação e poder. São Paulo: Cortez, 1999.

GONDRA, J. G. Excelência e exclusão. Rio de Janeiro: Biblioteca do Colégio de Aplicação da UERJ, 1997. Mimeografado.

GRAMSCl, A. Concepção dialética da história. Rio de Janeiro: Civilização Brasileira, 1998.

HABERMAS, J. La lógica de las ciencias sociales. Madri: Tecnos, 1988.

JODELET, D. La representation social: fenômeno, concepto y teoria. In: MOSCOVICl, S. (Org.). Psicologia social. Barcelona: Paidós, 1993.

Représentations sociales: un domaine en expansion. In: JODELET, D. (Ed.) Les représentations sociales. Paris: PUF, 1989.

JOVCHELOVITCH, S. Representações sociais: a construção simbólica dos espaços públicos no Brasil. Petrópolis: Vozes, 2000.

LINHARES, C. O direito ao saber com sabor: educação de professores na escola pública. Niterói: Faculdade de Educação, Universidade Federal Fluminense, 2000. Trabalho acadêmico.

LÜDKE, M.; ANDRÉ, M. E. D. Pesquisa em educação: abordagem qualitativa. São Paulo: Loyola, 1996.

MADEIRA, M. Um aprender do viver: educação e representação social. In: MOREIRA, A .S. P.M.; OLIVEIRA, D.C. (Org.). Estudos interdisciplinares de representação social.

Goiânia: AB Ed., 1998. p. 239-249.

MANCEBO, D. Da gênese utilitária aos compromissos: uma história da Universidade do Estado do Rio de Janeiro (1950-1978). 1995. Tese (Doutorado)- Pontifícia Universidade Católica de São Paulo, São Paulo, 1995.

MOSCOVICl, S. A representação social da psicanálise. Rio de Janeiro: Zahar, 1990.

NAGLE, J. A educação e sociedade na Primeira República. São Paulo: EPU; Rio de Janeiro: FENAME, 1974.

NÓVOA, A. Profissão professor. 2. ed. Porto, PT: Porto Ed., 1998. 
NUNES, C. Escola básica e cidadania: notas para um debate. In. (Org.).

Escola e cidadania: aprendizado e reflexão. Salvador, BA: OEA, UFBA, EGBA, 1990. . Escola \& dependência: o ensino secundário e a manutenção da ordem. Rio de Janeiro: Achimé, 1979.

OLIVEIRA, F. Uma alternativa democrática ao liberalismo. In: WEFFORT, F. et al. A democracia como proposta. Rio de Janeiro: IBASE, 1991.

. Medusa ou classes médias e a consolidação democrática. In: REIS, F. W.; O'DONNELL, G. (Org.). A democracia no Brasil: dilemas e perspectivas. São Paulo: Vértice, 1988. p. 258-292.

Réquiem para um falsificador. Folha de São Paulo, São Paulo, 7 ago. 1998. Caderno Tendências e Debates, p. 2.

ORLANDI, E. P. Discurso e leitura. 4. ed. Campinas: Editora da Unicamp, 1997. $\overline{\text { Vozes, }} 1996$.

Interpretação: autoria, leitura e efeitos do trabalho simbólico. Petrópolis, RJ:

A linguagem e seu funcionamento: as formas do discurso. 3. ed. Campinas, SP: Editora da Unicamp, 1999.

SARTORI, G. A teoria da democracia revisitada: o debate contemporâneo. 3. ed. São Paulo: Ática, 2000a.

A teoria da democracia revisitada: as questões clássicas. 3. ed. São Paulo: Ática, 2000b.

SILVA, T. T. Identidade e diferença: a perspectiva dos estudos culturais. Petrópolis: Vozes, 2000.

- Identidades terminais: as transformações na política da pedagogia e na pedagogia da política. Petrópolis: Vozes, 1996.

. Quem escondeu o currículo oculto? In: . Documentos de identidade: uma introdução às teorias do currículo. Belo Horizonte: Autêntica, 1999.

TEIXEIRA, A. A educação e a crise brasileira. São Paulo: Cia Editora Nacional, 1956.

TOURAINE, A. Crítica da modernidade. Petrópolis, RJ: Vozes, 1994.

Igualdade e diverisidade: o sujeito democrático. 3. ed. Bauru, SP: EDUSP, 1998.

O que é democracia? Petrópolis, RJ: Vozes, 1996.

\section{Correspondência:}

m_kaiuca@hotmail.com 